As-Syifaa Jurnal Farmasi Desember 2020;12(2):117-122.

ISSN : 2502-9444 (electronic); 2085-4714 (printed)

Journal Homepage : http://jurnal.farmasi.umi.ac.id/index.php/as-syifaa

\title{
UJI AKTIVITAS ANTIOKSIDAN ISOLAT FUNGI ENDOFIT DAUN GALING-GALING (Cayratia trifolia L.) DENGAN METODE 1,1-DIPHENYL-2-PICRYLHYDRAZIL (DPPH)
}

\author{
Magfirah Abdullah, Fitriana, St. Maryam
}

Fakultas Farmasi Universitas Muslim Indonesia, Makassar Email : magfirahabdullah@gmail.com

\begin{abstract}
Endophytic fungi generally produce secondary metabolites that have beneficial biological activities such as anticancer, antiviral, antibacterial or antioxidant compounds. The aim of this study was to examine the antioxidant activity of galling-galing leaf endophytic fungi isolate (Cayratia trifolia L.) by 1,1-diphenyl-2-picrylhydrazil (DPPH) method. This study used IDGG-03 endophytic fungi isolate fermented for 21 days using MYB medium then extracted and evaporation was carried out. The fermentate extract obtained was then tested qualitatively and quantitatively for antioxidant activity. Qualitative results using TLC plates indicate that galling-leaf fungi isolates have antioxidant activity which is characterized by the presence of yellow spots on a purple background. And in the quantitative test IC50 68,133 $\mu \mathrm{g} / \mathrm{mL}$ was obtained, which indicated the antioxidant activity of galling-vane leaf endophytic fungi isolate (Cayratia trifolia L.) classified as a strong antioxidant.
\end{abstract}

Key words: Antioxidants, Cayratia trifolia L., endophytic fungi, 1,1-diphenyl-2-picrylhydrazil (DPPH).

\section{PENDAHULUAN}

Pada tumbuhan banyak terdapat fungi endofit, berbagai jenis tumbuhan terutama tanaman obat, sehingga dapat digunakan sebagai sumber isolat fungi endofit. Fungi endofit adalah kelompok jamur yang sebagian atau seluruh hidupnya berada dalam jaringan tumbuhan hidup dan biasanya tidak merugikan inangnya.

Fungi endofit umumnya memproduksi metabolit sekunder yang memiliki aktivitas biologis yang bermanfaat seperti misalnya senyawa-senyawa antikanker, antivirus, atau antibakteri. $^{1}$

Fungi endofit yang tumbuh pada jaringan tumbuhan obat, juga dapat menghasilkan senyawa yang memilki khasiat sama dengan tanaman inangnya, walaupun jenis senyawanya berbeda. Sementara itu, senyawa yang dihasilkan fungi endofit sering kali memiliki aktivitas yang lebih besar dibandingkan senyawa dari tanaman inangnya. $^{2}$ Kemampuan dari mikroba endofit memproduksi senyawa metabolit sekunder sesuai dengan tanaman inangnya merupakan peluang yang sangat besar untuk memproduksi metabolit sekunder dari mikroba endofit yang diisolasi dari tanaman inangnya tersebut. ${ }^{3}$ Salah satu tumbuhan yang dapat digunakan sebagai sumber isolat fungi endofit adalah daun galing-galing (Cayratia trifolia L.).

Pada penelitian sebelumnya yang dilakukan oleh oleh Annisa Almaghfirah Achmar (2018) terkait Profil Bioautogram Isolat Fungi Endofit dari daun galling-galing sebagai antibakteri, yang dimana dilakukan identifikasi komponen kimia dan didapatkan hasil positif mengandung Flavonoid yang merupakan alah satu senyawa yang dapat berkhasiat sebagai antioksidan. Senyawa flavonoid diketahui mampu berperan menangkap radikal bebas atau berfungsi sebagai antioksidan alami. ${ }^{4}$ 
Uji Aktivitas Antioksidan Isolat Fungi Endofit Daun Galing-Galing (Cayratia trifolia L.) dengan Metode 1,1-Diphenyl-2-Picrylhydrazil (DPPH)

Selain itu, penelitian uji aktivitas antioksidan terhadap ekstrak daun tanaman galing-galing (Cayratia trifolia L.) telah diteliti oleh Rumayati tahun 2014 dan memperoleh hasil adanya aktivitas antioksidan pada ekstrak daun galinggaling (Cayratia trifolia L.).

Maka dari itu, pada penelitian ini akan dilakukan sebagai pengujian lebih lanjut mengenai aktivitas antioksidandaun gallinggaling (Cayratia trifolia L.) dengan mengisolasi fungi endofit dan menarik metabolit sekunder yang diproduksi oleh fungi endofit untuk diketahui aktivitas antioksidannnya dengan metode peredaman radikal bebas DPPH.

\section{METODE PENELITIAN}

\section{Alat dan Bahan}

Alat yang digunakan yaitu autoklaf (SMIC Model YX-280 B), cawan petri (Normax), fermentor, gelas Erlenmeyer (Iwaki Pyrex), gelas kimia 250 dan $500 \mathrm{ml}$ (Iwaki Pyrex), inkubator (Memert), Laminar Air Flow (LAF), lampu UV 254 nm dan 366 nm, lempeng KLT G60 F254 (E.Merck), oven (Memert), pipa kapiler, timbangan analitik (Chyo), vial dan jarum ose. Bahan-bahan yang digunakan pada penelitian ini adalah daun galing-galing (Cayratia trifolia L.), aquadest,DPPH (1,1diphenyl-2-picrylhydrazil) 100 ppm, etil asetat, medium Potato Dextrose Agar (PDA), medium Maltosa Yeast Broth (MYB), metanol pro analisis.

\section{Prosedur Kerja}

\section{Sterilisasi Alat dan Bahan}

Alat-alat yang digunakan dicuci hingga bersih dengan air suling, kemudian alat-alat gelas disterilkan dengan menggunakan oven pada suhu $180^{\circ} \mathrm{C}$ selama 2 jam, serta medium disterilkan dalam autoklaf pada suhu $121^{\circ} \mathrm{C}$ selama 15 menit. $^{5}$

\section{Pemurnian kultur fungi endofit}

Isolat fungi endofit diambil dengan menggunakan kawat ose dan dipindahkan ke medium Potato Dextrosa Agar Chloramfenikol (PDAC) baru untuk ditumbuhkan kembali dengan cara menggoreskan kawat ose pada jamur lalu ditusukkan di tengah-tengah medium baru. Kemudian diinkubasi pada suhu ruangan selama $3 \times 24$ jam. $^{6}$

\section{Fermentasi isolat aktif}

Isolat aktif kemudian diambil dengan menggunakan ose dan dimasukkan ke dalam tangki fermentor yang berisi $2000 \mathrm{~mL}$ medium cair Maltosa Yeast Broth (MYB), selanjutnya dilakukan fermentasi menggunakan Fermentor dengan kecepatan 200 rpm pada suhu ruangan selama 21 hari.

\section{Ekstraksi fermentasi isolat fungi endofit}

Hasil dari fermentasi akan diperoleh supernatan dan miselia yang disaring menggunakan kertas saring kemudian diambil supernatannya dan diekstraksi dengan metode ekstraksi cair-cair menggunakan etil asetat. ${ }^{7}$

\section{Pengujian Kualitatif}

Pengujian dilakukan dengan cara ekstrak fermentat dilarutkan dengan pelarut yang digunakan pada ekstraksi, kemudian ditotolkan pada plat KLT dengan menggunakan pipa kapiler. Plat yang sudah ditotolkan selanjutnya dielusi dengan eluen yang sesuai. Selanjutnya disemprot dengan reagen DPPH hingga permukaan terbasahi secara menyeluruh dan dibiarkan selama beberapa menit pada ruanagan tertutup. Setelah itu, bercak muncul diamati. ${ }^{8}$

\section{Pengujian Kuantitatif}

Pengujian dilakukan dengan cara membuat variasi konsentrasi (5 ppm, 10 ppm, 25 ppm, 50 ppm, 100 ppm) dari ekstrak fermentasi. Masing-masing konsentrasi di pipet $1 \mathrm{~mL}$, 
Uji Aktivitas Antioksidan Isolat Fungi Endofit Daun Galing-Galing (Cayratia trifolia L.) dengan Metode 1,1-Diphenyl-2-Picrylhydrazil (DPPH)

ditambahkan metanol p.a $4 \mathrm{~mL}$ lalu ditambahkan larutan DPPH 0,04\%. Campuran yang telah dibuat tersebut kemudian dikocok dan diinkubasi dalam kondisi gelap selama 30 menit. Setelah itu, dilakukan pengukuran terhadap absorbansi dari masing-masing campuran menggunakan spektrofotometri UVVis pada panjang gelombang $517 \mathrm{~nm}$. Pada uji ini vitamin $\mathrm{C}$ digunakan sebagai standar. ${ }^{9}$

\section{HASIL DAN PEMBAHASAN}

Tabel 1. Persentase inhibisi dan Nilai $I_{50}$ dari Ekstrak fermentat daun galling-galing (Cayratia trifolia L.)

\begin{tabular}{ccc}
\hline Kosentrasi (ppm) & \%inhibisi & $\mathbf{I C}_{50}(\boldsymbol{\mu g} / \mathbf{m L})$ \\
\hline 5 & 26,157 & \\
10 & 27,033 & \\
25 & 34,918 & 69,193 \\
50 & 42,553 & \\
100 & 61,451 & \\
Blanko & - & \\
\hline
\end{tabular}

Tabel 2. Persentase inhibisi, dan Nilai $\mathrm{IC}_{50}$ dari Pembanding Asam Askorbat

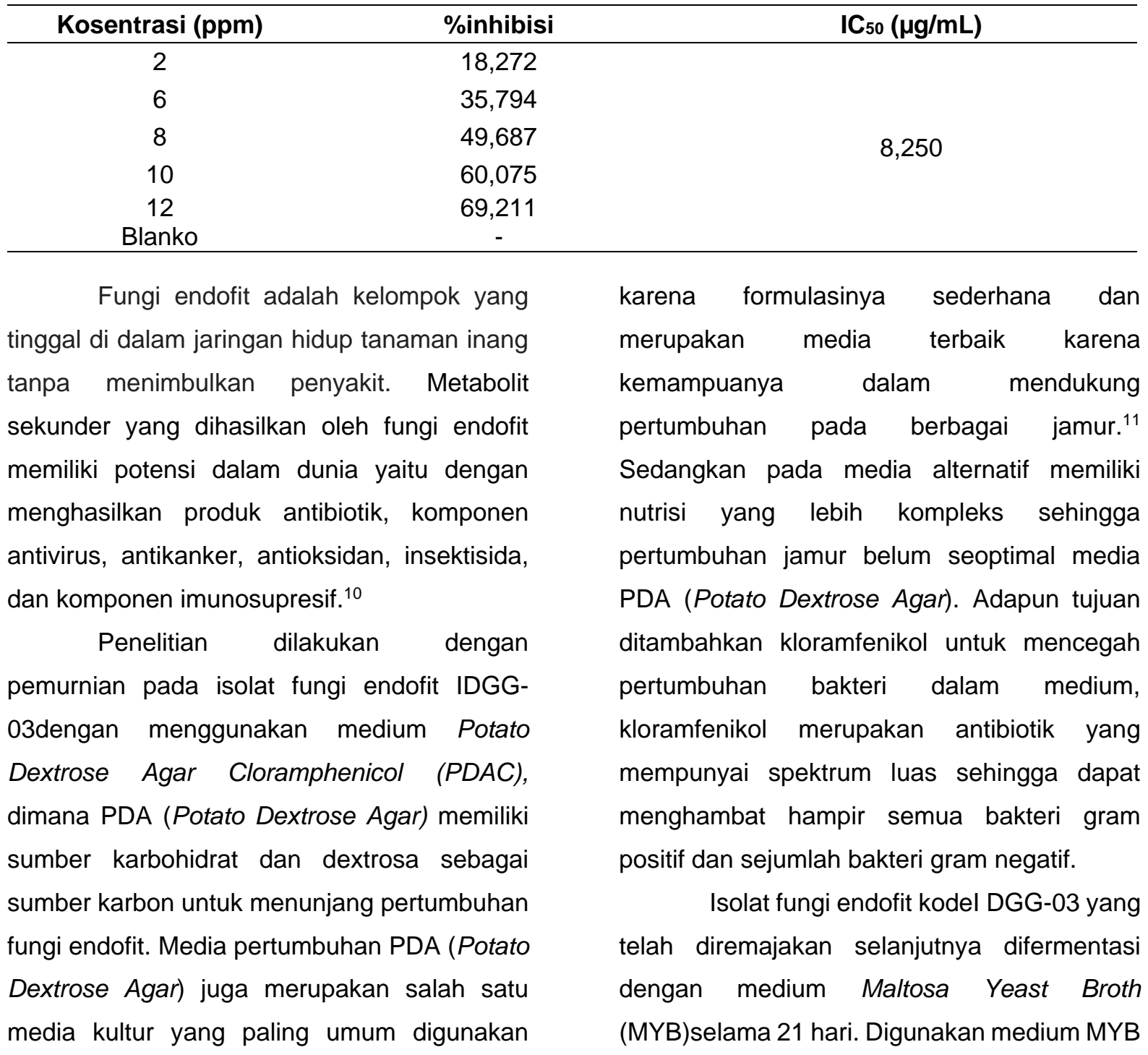


karena medium ini merupakan medium cair yang mengandung ekstrak yeast sebagai sumber protein, maltosa serta dextrosa sebagai sumber karbon dan pepton sebagai sumber asam amino yang dibutuhkan dalam pertumbuhan sintesis sel serta keperluan energi metabolisme mikroorganisme. ${ }^{12}$ Fermentasi dilakukan 21 hari karena pada hari ke-15 hingga ke-21 terjadi fase stationer dimana pertumbuhan fungi relatif tetap, pertumbuhan fungi seimbang dengan jumlah sel yang mati. Pada fase stationer meskipun karbon sebagai sebagai sumber energi atau nutrisi yang penting telah habis digunakan, tidak berarti pertumbuhan terhenti dikarenakan terjadinya lisis pada sel mati dan digunakan sebagai sumber nutrisi. ${ }^{13}$

Ekstraksi cair-cair pada fermentat yang telah diperoleh dari proses fermentasi dilakukan dengan menggunakan pelarut etil asetat. Dilakukan ekstraksi dengan menggunakan pelarut etil asetat. Etil asetat merupakan pelarut organik yang bersifat semipolar dan sering digunakan untuk mengekstraksi kultur fungi endofit. ${ }^{14}$ Sehingga diharapkan dapat mengekstrak lebih banyak komponen polar maupun non-polar dan mudah dipisahkan dengan cairan MYB yang besifat polar. Selain itu, etil asetat merupakan pelarut yang baik digunakan untuk melarutkan senyawa-senyawa yang berpotensi sebagai antioksidan. ${ }^{15}$ Ekstrak yang diperoleh kemudian diuapkan dan didapatkan ekstrak kental sebanyak $40 \mathrm{mg}$.

Uji aktivitas antioksidan dilakukan menggunakan metode pengukuran serapan radikal DPPH secara kualitatif dan kuantitatif. Uji radikal DPPH secara luas digunakan, dikarenakan metode DPPH cepat dan terpercaya untuk menguji kemampuan antioksidan dalam meredam radikal bebas. ${ }^{16}$ Pada metode lain selain DPPH membutuhkan reagen kimia yang cukup banyak, waktu analisis yang lama, biaya yang mahal dan tidak selalu dapat diaplikasikan pada semua sampel. ${ }^{17}$

Pengujian aktivitas antioksidan secara kualitatif dilakukan dengan menggunakan KLT (Kromatografi Lapis Tipis) untuk mengetahui ada atau tidaknya senyawa aktif dari isolat daun galing-galing (Cayratia trifolia L.) yang memiliki aktivitas antioksidan dalam meredam radikal bebas.Senyawa yang mempunyai aktivitas antioksidan akan bereaksi dengan DPPH yang berwarna ungu dan berubah menjadi warna kuning, senyawa yang lebih stabil. Senyawa antioksidan akan bereaksi dengan radikal DPPH melalui mekanisme donasi atom hidrogen dan menyebabkan terjadinya peluruhan warna dari ungu ke kuning. ${ }^{18}$

Berdasarkan hasil pengujian kualitatif menunjukkan bahwa ekstrak isolat IDGG-03 memiliki potensi sebagai antioksidan dengan noda warna kuning berlatar belakang ungu. Selanjutnya dilakukan pengujian secara kuantitatif dengan menggunakan spektrofotometer UV-Vis. Dibuat larutan stok 1000 ppm dari ekstrak fermentat fungi IDGG03 dan dilarutkan menggunakan metanol p.a. penggunaan metanol p.a dikarenakan metanol p.a tidak mempengaruhi reaksi antara sampel uji sebagai antioksidan dengan DPPH sebagai radikal bebas. ${ }^{18}$

Selanjutnya dilakukan pengujian secara kuantitatif menggunakan spektrofotometer UV-Vis. Dibuat larutan stok 1000 ppm dari ekstrak fermentat fungi IDGG03 dan dilarutkan menggunakan metanol p.a. Penggunaan metanol p.a dikarenakan metanol 
p.a tidak mempengaruhi reaksi antara sampel ujisebagai antioksidan dengan DPPH sebagai radikal bebas. ${ }^{18}$ Variasi konsentrasi yang digunakan pada sampel yakni $5 \mathrm{ppm}, 10 \mathrm{ppm}$, 25 ppm, 50 ppm dan 100 ppm. Sedangkan untuk konsentrasi pembanding sebesar 2 ppm, 6 ppm, 8 ppm, 10 ppm dan 12 ppm. Pembanding yang digunakan sebagai kontrol positif adalah asam askorbat. Alasan penggunaan asam askorbat sebagai pembanding karena asam askorbat merupakan senyawa murni yang memiliki aktivitas antioksidan kuat terbukti dengan nilai $\mathrm{IC}_{50}$ kecil . Asam askorbat mudah mengalami oksidasi oleh radikal bebas karena mempunyai ikatan rangkap serta terdapat 2 gugus $-\mathrm{OH}$ yang terikat pada ikatan rangkap tersebut. Asam askorbat mampu menangkap radikal bebas dengan atau tanpa katalisator enzim. Reaksinya terhadap senyawa oksigen reaktif lebih cepat dibandingkan dengan komponen cair lainnya. ${ }^{19}$ Kemudian dari masing masing konsentrasi ditambahkan larutan DPPH $1 \mathrm{~mL}$ dan dicukupkan dengan methanol p.a sampai 5 $\mathrm{mL}$. Dihomogenkan dan diinkubasi selama 30 menit pada ruangan gelap karena DPPH sangat peka terhadap cahaya. Tujuan dari inkubasi adalah agar sampel tersebut dapat bereaksi dengan DPPH secara sempurna. Menurut Lailiyah (2014) Sampel yang diinkubasi akan lebih stabil serta memiliki penurunan absorbansi yang lebih singnifikan dibandingkan sampel yang tidak diinkubasi. Pengukuran dilakukan pada panjang gelombang 517 disebabkan DPPH memberikan penyerapan kuat di $517 \mathrm{~nm}$ karena ganjilnya elektron. Dilakukan perihitungan persen inhibisi untuk digunakan dalam membuat persamaan garis regresi linear yang digunakan dalam menentukan nilai $\mathrm{IC}_{50}$.
Nilai $\mathrm{IC}_{50}$ (Inhibitor Concentration) merupakan parameter yang digunakan untuk mengetahui tingkat peredaman sampel terhadap radikal DPPH, yaitu konsentrasi aktivitas antioksidan yang menghambat $50 \%$ radikal bebas $\mathrm{DPPH}$.

Dibuat persamaan regresi linear antara konsentrasi (ppm) sebagai absisnya (sumbu $\mathrm{x}$ ) dan persen inhibiai sebagai ordinatnya (sumbu y). Dan dari persamaan regresi tersebut dapat ditentukan nilai $\mathrm{IC}_{50}$. Persamaan regresi linear yang dihasilkan pada ekstrak fermentat isolat daun galling-galing (Cayratia trifolia L.) kode IDGG-03 yaitu $y=0,375 x+24,45$ dengan nilai $R^{2}$ sebesar 0,996 . Sedangkan persamaan regresi linear pembanding asam askorbat adalah $y=5,219 x+6,940$ dengan nilai $R^{2}$ sebesar 0,994. Kemudian dari regresi linear tersebut dimasukkan dalam persamaan garis lurus $\mathrm{y}=\mathrm{bx}+\mathrm{a}$ untuk menentukan nilai $\mathrm{IC}_{50}$.

Berdasarkan hasil perhitungan nilai IC 50v $_{\text {v }}$ ekstrak fermentat IDGG-03 termasuk antioksidan kuat karena nilai $\mathrm{IC}_{50}$ berada pada kisaran 50-100 $\mu \mathrm{g} / \mathrm{mL}$ yaitu $69,193 \mu \mathrm{g} / \mathrm{mL}$. Sedangkan pembanding Asam askorbat termasuk antioksidan sangat kuat karena memiliki nilai $\mathrm{IC}_{50}$ kurang dari $50 \mu \mathrm{g} / \mathrm{mL}$ yaitu $8,250 \mu \mathrm{g} / \mathrm{mL}$.

\section{KESIMPULAN}

Berdasarkan penelitian yang dilakukan dapat disimpulkan bahwa Ekstrak fermentat isolat fungi endofit daun galling-galing (Cayratia trifolia L.) kode IDGG-03 memiliki nilai $\mathrm{IC}_{50}$ sebesar $69,193 \mu \mathrm{g} / \mathrm{mL}$ dan termasuk antioksidan kuat

\section{DAFTAR PUSTAKA}

1. Hasiani VV, Ahmad I, Rijai L. Isolasi Jamur Endofit dan Produksi Metabolit Sekunder Antioksidan dari Daun Pacar (Lawsonia inermis L.). Jurnal Sains dan Kesehatan. 2015;1(4): 146-153.

2. Prihatiningtias $\mathrm{W}$, Wahyuningsih, $\mathrm{MSH}$. Prospek Mikroba Endofit Sebagai Sumber 
Senyawa Bioaktif. Jogjakarta. Fakultas Farmasi Universitas Gadjah Mada, 2006.

3. Radji M. Peranan Bioteknologi dan Mikroba Endofit dalam Pengembangan Obat Herbal. Majalah IImu Kefarmasian. 2005;2(3).

4. Kuncahyono I and Sunardi. Uji Aktivitas Antiokisdan Ekstrak Belimbing Wuluh (Averrhoa bilimbi L.) Terhadap 1,1Diphenyl-2-Picrylhidrazyl (DPPH). Seminar Nasional Teknologi. 2007:1-9.

5. Elliott T. Mikrobiologi Kedokteran \& Infeksi. Jakarta. EGC, 2013.

6. Kjer J, Debbab A, Aly AH, Proksch P. Methods for isolation of marine-dereved endophytic fungi and their bioactive secondary products. Nat Protoc. 2010;5(3);479-90

7. Noverita. Identifikasi Kapang dan Khamir Penyebab Penyakit Manusia pada Sumber Air Minum Penduduk pada Sungai Ciliwung dan Sumber Air Sekitarnya. Vis Vitalis. 2009;2(2):15-19.

8. Cholisoh Z and Utami W. Aktivitas penangkap Radikal Ekstrak Etanol 70\% Biji Jengkol (Archidendron jiringa). PHARMACON. 2008;9(1):33-40.

9. Kumala S. Antimicrobial Activity of Secondary Metabolites Produced by Endophytic Fungi Isolated from Stems of Jati Tree (Tectona grandis L.F). International Journal of Pharmacetiucal Science and Research. 2015;6(6):23492353.

10. Strobel GA. Natural Products from Endophytic Microorganism. Journal Natural Product, 2004.

11. Saha A, Mandal P, Dasgupta S, Saha D. Influence of Culture Media and Environmental Factors an Mycelia Growth and Sporulation of Lasiopdiplodia the obromae (Pat.) Griffon and Maubl. Journal of Enviromental Biology. 2008;29(3):407410.

12. Fitriana, Maryam St, Naid T, Maryana. Penelusuran Fungi Endofit Sebagai Penghasil Senyawa Antibiotika dari Daun Nanas (Ananas comosus (L) Merr). Jurnal Farmasi Asy-Syifaa. 2016;8(01):01-08

13. Rendowaty A, Djamaan A and Handayani D. Waktu Kultivasi Optimal dan Aktivitas Antibakteri dari Ekstrak Etil Asetat Jamur Simbion Aspergillus unguis (WR8) dengan Haliclona fascigera. Jurnal Sains Farmasi. 2017;4(2):49-54.

14. Sarker SD, Nahar L. Chemistry for Pharmacy Student (General, Organic and Natural Product Chemistry). Chichester: J Wiley, 2007.

15. Arora, Daljit S. Assay of Antioxidant Potential of Two Aspergillus Isolates by Different Methods Under Various PhysioChemical Conditions. Brazilian Journal of Microbiology. 2009;41:765-777.

16. Srujana M, Lakhmidevi N. Antioxidant Studies of Methanolic Extract and Active Fraction Obtained From Ichnocarpus frutescens. Antioxidant determinations by the use of a stable free radical. International Journal of Pharma and Bio Science. 2017;8(1):110-117.

17. Sayuti K and Yenrina R. Antioksidan Alami dan Sintetik. Padang. Andalas University Press, 2015.

18. Handayani S, Najib A and Wati NP. Uji Aktivitas Antioksidan Ekstrak Daun Daruju (Acanthus ilicifolius L.) Dengan Metode Peredamna Radikal Bebas 1,1-Diphenyil2-Picrylhidrazil (DPPH). Jurnal Fitofarmaka Indonesia. 2018;5(2):299-308.

19. Winarsi H. Antioksidan Alami dan Radikal Bebas. Yogyakarta: Kanisius., 2011. 